\title{
E-Wom Oleh Kalangan Milenial Terhadap Akun @makansampaikenyang Sebagai Pemberi Rekomendasi Kuliner
}

\author{
Chintya Viviana, Diah Ayu Candraningrum \\ chintya.915150043@stu.untar.ac.id,diahc@fikom.untar.ac.id
}

Fakultas Ilmu Komunikasi Universitas Tarumanagara

\begin{abstract}
Humans are social beings who cannot live alone, so humans always interact through communication with other humans. In this modern era, communication activities are supported by the presence of new media, such as social media. The existence of social media allows users to be able to access information quickly and easily. Then appear a person called food bloggers as cause of developing technologies that giving so many influences in various field, one of which is the culinary field, the present food which has aesthetic value and can be used as a photo object, then reviewed. This study uses a descriptive qualitative approach. In this study the highlights were followers included in the millennial generation. The conclusion that the researcher got is that Instagram is a social media that is very familiar with the millennial generation, besides the blogger's popularity which is not separated from the role of people who become their followers, it is also supported by the presence of electronic word of mouth communication marketing because the followers promoted food blogger's account via Instagram. Food bloggers also use interaction features on Instagram to be more familiar and to maintain the engagement with their followers.
\end{abstract}

Keywords : Food Blogger, Followers, E-WOM, Instagram.

\begin{abstract}
Abstrak
Manusia adalah makhluk sosial yang tidak dapat hidup sendiri, maka dari itu manusia selalu melakukan interaksi melalui komunikasi dengan manusia lainnya. Dalam era modern ini, kegiatan komunikasi didukung oleh adanya kemajuan di bidang teknologi dan melahirkan media baru, seperti media sosial. Adanya media sosial memungkinkan penggunanya untuk dapat mengakses informasi dengan cepat dan mudah. Kemudian muncul tokoh yang disebut sebagai food blogger sebagai akibat dari adanya perkembangan teknologi memberikan pengaruh dalam berbagai bidang, salah satunya adalah bidang kuliner, makanan kini dianggap memiliki nilai estetika dan dijadikan sebagai objek foto, kemudian diberi ulasan. Penelitian ini menggunakan pendekatan kualitatif deskriptif. Dalam penelitian ini yang disoroti adalah followers yang termasuk dalam generasi milenial. Simpulan yang peneliti dapatkan adalah Instagram merupakan media sosial yang sangat akrab di kalangan generasi milenial, selain itu kepopuleran food blogger tak lepas dari peranan sekelompok orang yang menjadi followersnya, hal tersebut juga didukung oleh adanya pemasaran dari mulut ke mulut, dalam konteks ini electronic word of mouth yang berperan karena pemasaran akun food blogger dilakukan oleh followers melalui media sosial Instagram. Food blogger juga berupaya melakukan interaksi melalui fitur yang ada di Instagram agar lebih akrab dengan para followersnya.
\end{abstract}

Kata Kunci : Food Blogger, Followers, E-WOM, Instagram. 


\section{Pendahuluan}

Manusia diciptakan sebagai makhluk multidimensional, memiliki akal pikiran dan kemampuan berinteraksi secara personal maupun sosial. Karena manusia adalah makhluk sosial, maka manusia pada dasarnya tidak mampu hidup sendiri di dalam dunia ini baik dalam konteks fisik maupun dalam konteks sosial-budaya. Pada era modern ini kegiatan komunikasi manusia telah dipengaruhi dan didukung oleh kecanggihan teknologi di belakangnya yang juga dapat menunjang komunikasi antarindividu. Kemajuan teknologi membuat manusia berusaha untuk menyesuaikan diri dan mengikuti perkembangan yang ada. Hal ini tentunya mempermudah penggunanya untuk mendapatkan informasi dalam waktu yang singkat. Media sosial merupakan salah satu bentuk media baru, ciri-cirinya adalah merupakan konten online yang memungkinkan para pengguna internet untuk dapat mengakses informasi dengan cepat dan mudah.

Perkembangan teknologi saat ini memberikan pengaruh yang sangat signifikan di berbagai bidang, salah satunya dalam bidang kuliner. Makanan yang menjadi kebutuhan pokok manusia sekarang menjadi sesuatu yang bernilai estetika dan tak jarang menjadi objek foto. Hal tersebut mendukung terbentuknya sekumpulan orang yang membentuk komunitas kuliner yang disebut food blogger. Menurut Ollie (2012), food bloggers adalah orang-orang yang suka mencoba tempat makan baru dan posting foto-foto makanan tersebut pada blog-nya. Media sosial yang akan diteliti pada penelitian ini adalah Instagram.

Instagram merupakan sebuah jejaring sosial berbasis fotografi yang tercipta pada tahun 2010. Selain foto, penggunanya juga dapat mengunggah video, story, dan memungkinkan untuk saling mengirimkan komentar, likes, dan messages secara pribadi kepada pengguna lainnya. Seperti yang dapat dilihat pada gambar di bawah, lembaga survei penggunaan media sosial 'We Are Social' yang berbasis di London menempatkan Instagram berada di posisi keempat sebagai media sosial yang paling banyak digunakan oleh penduduk di Indonesia.

Gambar 1.1 Media Sosial Yang Digunakan Oleh Penduduk Indonesia

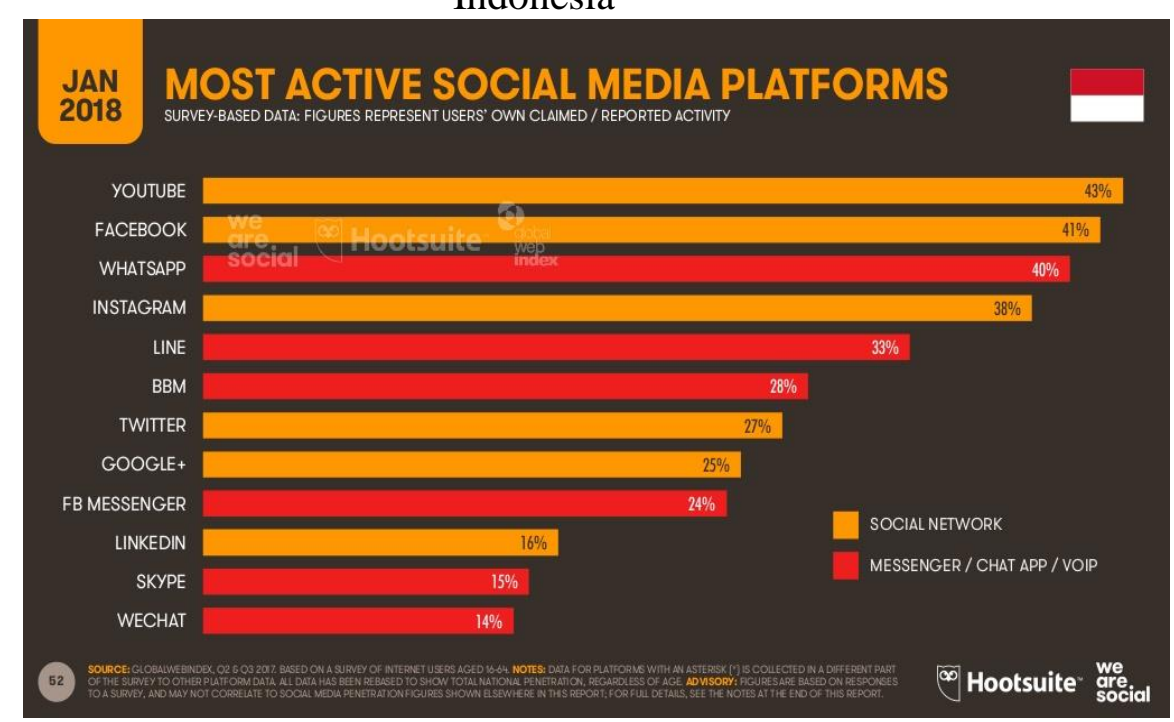

Sumber : https://www.slideshare.net/wearesocial 
Chintya Viviana, Diah Ayu Candraningrum: E-Wom Oleh Kalangan Milenial Terhadap Akun @ makansampaikenyang Sebagai Pemberi Rekomendasi Kuliner

Latar belakang di atas memotivasi penulis untuk melakukan penelitian mengenai food blogger yang saat ini sangat eksis di media sosial. Tokoh food blogger yang akan diteliti oleh penulis adalah Prathama Gilang pemilik akun @ makansampaikenyang yang sekarang memiliki lebih dari 61 ribu followers dengan 5 ribu unggahan di Instagramnya (per tanggal 21 September 2018). Selain itu ada beberapa food blogger aktif lainnya, seperti @cnlulaby, dan@thefoodshunter.

TABEL 1.1 Perbandingan Beberapa Food Blogger

\begin{tabular}{llll}
\hline Nama Akun & @makansampaikenyang & @ cnlulaby & @ thefoodshunter \\
\hline $\begin{array}{l}\text { Nama } \\
\text { Pemilik }\end{array}$ & Prathama Gilang & Cindy & Juwita \& Dita \\
Jumlah & 61.4 Ribu & 39.9 Ribu & 35.1 Ribu \\
Followers & Juni 2014 & Maret 2014 & Oktober 2017 \\
Berdiri Sejak & Jun &
\end{tabular}

Sumber : Hasil Observasi Penulis, 2018

Berdasarkan hal yang penulis paparkan di atas maka terbentuklah sebuah rumusan masalah sebagai berikut: Bagaimana Penggunaan E-WOM Oleh Kalangan Milenial Terhadap Akun Instagram @makansampaikenyang Sebagai Pemberi Rekomendasi Kuliner? Tujuan dari dilakukannya penelitian ini adalah untuk mendeskripsikan penggunaan E-WOM oleh kalangan milenial terhadap akun Instagram@makansampaikenyang sebagai pemberi rekomendasi kuliner dan untuk mengetahui penggunaan Instagram yang dilakukan oleh akun @ makansampaikenyang sebagai pemberi rekomendasi kuliner.

Peneliti akan memaparkan beberapa teori yang digunakan dalam penelitian ini, diantaranya adalah generasi milenial, food blogger, Instagram, dan electronic word of mouth communication. Generasi milenial yang disebut juga generasi Y, akrab disebut generation me atau echo boomers diciptakan oleh dua pakar sejarah dan penulis Amerika, William Strauss dan Neil Howe. Para pakar menggolongkannya berdasarkan tahun awal dan akhir. Penggolongkan generasi Y terbentuk bagi mereka yang lahir pada 1980-1990, atau pada awal 2000, dan seterusnya. Milenial sendiri dianggap special karena generasi ini sangat berbeda dengan generasi sebelumnya, apalagi dalam hal yang berkaitan dengan teknologi. (https://www.kominfo.go.id/content/detail/8566/mengenal-generasi-

millennial/0/sorotan_media diakses pada tanggal 29 November 2018 pukul 14.05 WIB).

Seseorang yang menulis dan mengulas tentang makanan dalam blognya dikenal dengan sebutan food blogger seperti yang diungkapkan Hanifati dalam Syahbani, Widodo (2017). Platform yang digunakan oleh food blogger untuk menulis ulasannya tidak terbatas pada blog saja namun juga media sosial seperti Instagram. Melalui Instagram, penggunanya dapat lebih mudah untuk membaca dan mendapatkan informasi dari food blogger melalui postingannya dan mengikuti rekomendasinya.

Instagram merupakan layanan jejaring sosial berbasis fotografi. Instagram memungkinkan penggunanya untuk membagikan gambar maupun video. Instagram dibuat oleh Kevin Systrom dan Mike Krieger pada 6 Oktober 2010. Menurut Bambang, instagram adalah sebuah jejaring sosial dalam media digital yang 
mempunyai fungsi untuk mengambil foto dalam bentuk atau tempat untuk berbagi informasi terhadap penggunanya.

Teknik pemasaran yang dilakukan oleh followers @makansampaikenyang adalah pemasaran dari mulut ke mulut melalui Instagram, maka dari itu dikategorikan sebagai electronic word of mouth. $e$-WOM merupakan teknik word of mouth communication yang dilakukan melalui internet. $e$-WOM merupakan pernyataan positif atau negatif yang dilakukan oleh konsumen potensial, aktual, maupun mantan kosnumen tentang produk atau perusahaan melalui internet. Dimensi electronic word of mouth (e-WOM) menurut Goyette et al dalam Priansa (2017) adalah intensitas (intensity), valence of opinion, content.

\section{Metode Penelitian}

Metodologi penelitian menurut Pujileksono (2015:4) adalah analisis teori atau ilmu yang membahas tentang tentang metode dalam melakukan penelitian. Jenis pendekatan yang digunakan oleh penulis dalam penelitian ini adalah pendekatan kualitatif yang bersifat deskriptif. Penelitian kualitatif adalah penelitian yang bermaksud untuk memahami fenomena tentang apa yang dialami oleh subjek penelitian misalnya perilaku, persepsi, motivasi, tindakan, dll secara holistik, dan dengan cara deskripsi dalam bentuk kata-kata dan Bahasa, pada suatu konteks khusus yang alamiah dan dengan memanfaatkan berbagai metode alamiah (Moleong, 2009:6).

Menurut Yin (2011) studi kasus adalah suatu inkuiri empiris yang menyelidiki fenomena di dalam konteks kehidupan nyata, bilamana batas-batas antara fenomena dan konteks tidak tampak secara tegas atau jelas dan menggunakan berbagai sumber atau multisumber bukti. Penelitian studi kasus dapat dibedakan menjadi tiga tipe, masing-masing adalah tipe eksplanatoris, yaitu untuk menjelaskan hubungan kausal dalam konteks kehidupan nyata. Tipe eksploratoris, yaitu digunakan untuk mengeksplorasi suatu situasi yang tidak dapat dievaluasi secara intevensi atau berdasarkan single point saja. Dan tipe berikutnya adalah deskriptif digunakan untuk mendeskripsikan fenomena yang terjadi pada kehidupan nyata. Pertanyaan penelitian berkenan dengan "W-H question" yaitu what, who, where, why how yang akan member rambu-rambu terhadap strategi penelitian yang digunakan. Dari bentuk pertanyaan diatas, studi kasus paling cocok menggunakan pertanyaan how dan why.

Subyek penelitian menurut Amirin (Idrus, 2009:91) merupakan seseorang atau sesuatu yang mengenainya ingin diperoleh keterangan. Kesimpulannya, subyek penelitian adalah individu, benda, atau organisme yang dijadikan sumber informasi yang dibutuhkan dalam pengumpulan data penelitian. Subyek yang digunakan oleh penulis dalam penelitian ini adalah followers akun@makansampaikenyang yang termasuk dalam golongan milenial dan akun @makansampaikenyang yang dikelola oleh Prathama Gilang. Obyek penelitian yang digunakan oleh penulis adalah Instagram sebagai media yang digunakan oleh akun @makansampaikenyang dan rekomendasi kuliner.

Teknik analisis data yang digunakan oleh penulis adalah model interaktif Miles dan Huberman. Aktivitas dalam analisis data menurut Miles dan Huberman (Sugiyono, 2011:337-345) yaitu: reduksi data (data reduction), penyajian data (data display), dan penarikan kesimpulan (verifikasi). Penulis melakukan triangulasi metode dan triangulasi teori. 
Chintya Viviana, Diah Ayu Candraningrum: E-Wom Oleh Kalangan Milenial Terhadap Akun @ makansampaikenyang Sebagai Pemberi Rekomendasi Kuliner

\section{Hasil Temuan dan Diskusi}

Berikut penulis jabarkan hasil temuan yang telah didapatkan:

a. Electronic Word of Mouth Digunakan Untuk Melakukan Promosi Oleh Pengguna Internet

Electronic Word of Mouth merupakan informasi dari mulut ke mulut yang dibagikan oleh sesama konsumen dalam media sosial untuk bahan petimbangan mengenai produk yang diteliti konsumen. Jenis pemasaran ini secara tak langsung digunakan oleh para pengguna media sosial. Dalam penelitian ini, followers akun @ makansampaikenyang yang diwawancarai oleh penulis telah melakukan electronic word of mouth communication dengan teman-temannya melalui sharing content melalui Instagram, aplikasi chat Line, atau Whatsapp. Dengan adanya pemasaran ini, sangat membuat akun yang dipromosikan menjadi dikenal orang lain.

b. Followers@makansampaikenyang Merupakan Pengguna Aktif Instagram

Untuk mendapatkan data, penulis melakukan wawancara dengan sejumlah pengguna Instagram yang menjadi followers @makansampaikenyang, berikut kriteria followers yang penulis wawancarai: (1) Merupakan follower @ makansampaikenyang, (2) Followers yang secara aktif memberi like pada postingan@makansampaikenyang, (3) Followers merupakan generasi milenial yang paham atas tren rekomendasi food blogger. Setelah melakukan wawancara, ternyata delapan orang followers yang penulis wawancarai adalah pengguna aktif Instagram, mulai menggunakan sejak tahun didirikannya Instagram yaitu tahun 2010 dengan waktu berjam-jam untuk mengakses tiap harinya.

c. Interaksi Dengan Followers Sangat Dibutuhkan

Seiring dengan kepopuleran yang diraih oleh food blogger maka harus diikuti dengan keeratan hubungan yang dibangun dengan para followersnya. Karena semakin dekat dan akrab dengan followers makan akan menjadi semakin loyal dan setia terhadap akun food blogger tersebut. Pada penelitian ini, penulis menemukan hal-hal yang dilakukan oleh food blogger untuk berinteraksi melalui media sosial dengan para followersnya, antara lain dengan memanfaatkan fiturfitur yang ada pada Instagram story, seperti: 'ask a question' yaitu pemilik akun dapat memberikan pertanyaan lalu followers dapat menjawabnya di answer box, fitur poll yang salah satunya dapat dipilih oleh followers kemudian akan muncul persentase jawaban. Selain itu, melalui interaksi, followers dapat mengenal lebih jauh sosok pemilik akun, seperti halnya followers @makansampaikenyang menilai Gilang sang pemilik akun sangat baik dan ramah, dan hal tersebut menjadi salah satu faktor mereka terus memfollow dan merekomendasikan akunnya kepada orang lain.

d. Konten Yang Dibagikan Kredibel dan Informatif

Konten adalah isi informasi dari situs jejaring sosial berkaitan dengan produk dan jasa. Melalui hasil wawancara yang dilakukan penulis, konten yang dibagikan oleh akun@makansampaikenyang sangat informatif dan berkredibilitas karena mereka seringkali mencoba makanan yang direkomendasikan dan hasilnya sesuai dengan ulasan yang diberikan oleh sang food blogger. Selain itu, foto yang diunggah oleh @makansampaikenyang cukup real dan tidak terlalu banyak editing sehingga memberikan kesan alami dan sesuai dengan apa yang tersaji di kenyataan. Hal ini membuat konten pada akun @makansampaikenyang mendapatkan banyak tanggapan positif dari para followersnya. 
Selain melalui wawancara, penulis mendapatkan data melalui observasi penggunaan Instagram oleh akun@makansampaikenyang dalam periode 14 hari, yaitu: 22 Oktober - 28 Oktober 2018 dan 13 November - 18 November 2018. Pada tanggal 22 Oktober hingga 28 Oktober 2018 @makansampaikenyang telah mengunggah 6 buah foto dan juga instastory, lalu pada tanggal 13 November - 18 November @makansampaikenyang mengunggah 6 foto dan instastory. Tak ada alasan tertentu pemilik akun memposting makanan tersebut, semua murni karena ia mengunjungi tempat tersebut atau makan di tempat tersebut karena tak semua yang diposting merupakan endorse.

Berikut penulis jabarkan hasil wawancara dengan followers @ makansampaikenyang secara singkat.

Tabel 1. Hasil Wawancara Follower Akun@makansampaikenyang

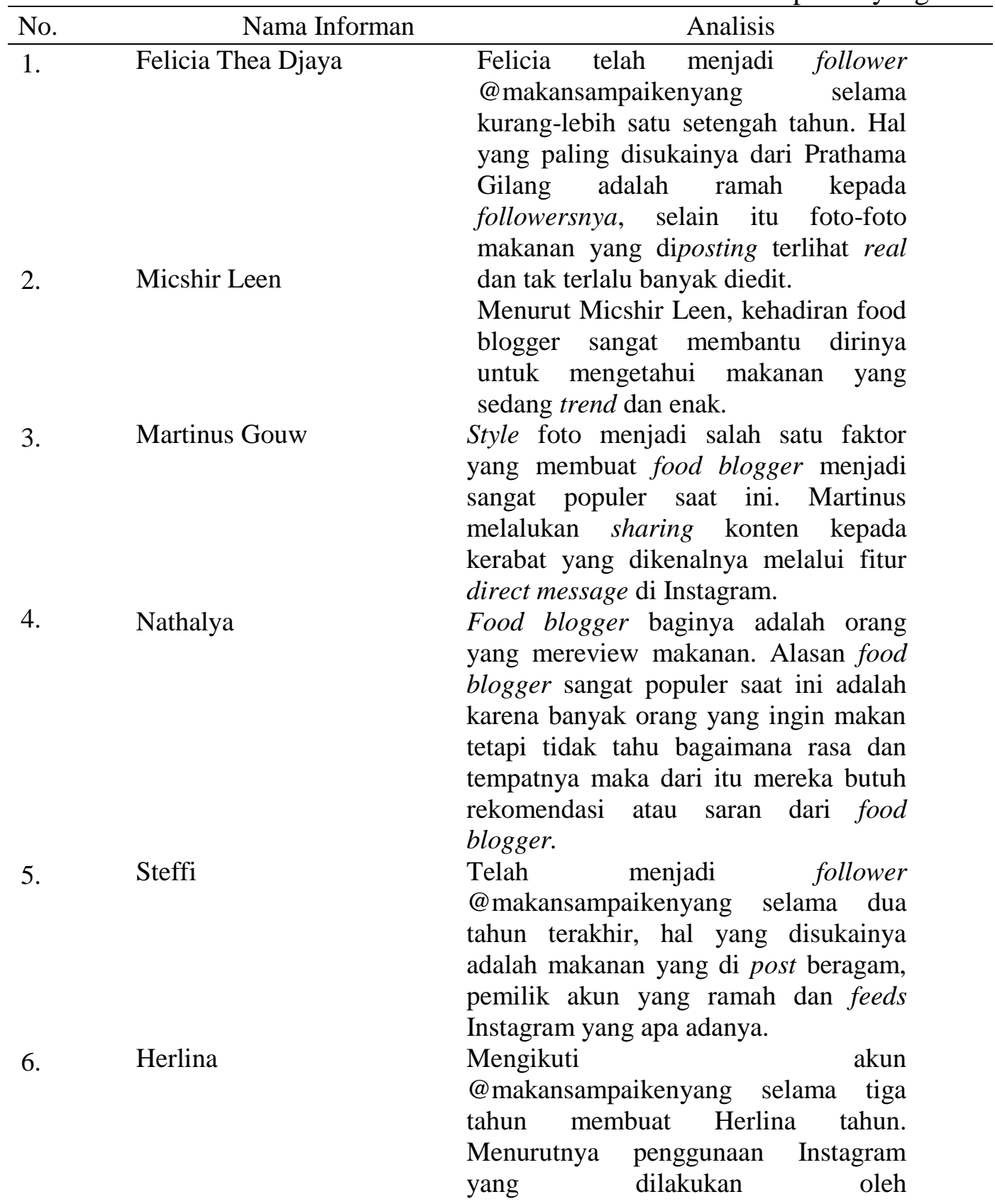


Chintya Viviana, Diah Ayu Candraningrum: E-Wom Oleh Kalangan Milenial Terhadap Akun @ makansampaikenyang Sebagai Pemberi Rekomendasi Kuliner

7. Maria Veronica

8. $\quad$ Fita Franika @makansampaikenyang cukup baik karena dapat mempermudah orang banyak.

Hal yang disukai Vero dari akun ini adalah foto yang bagus, review makanan yang detail, menarik dan jujur, dan pemilik akun yang ramah.

Food blogger bagi Fita adalah orang yang sering mencari makanan yang hits dan enak lalu diposting di akun Instagramnya.

Sumber: Dokumentasi Penulis (2018)

\section{Simpulan}

Dengan kehadiran food blogger di era media baru sangat membantu para pengguna sosial media untuk mengetahui informasi seputar kuliner yang patut untuk dicoba. Rekomendasi yang diberikan food blogger sangat membantu didukung dengan adanya followers yang secara tak langsung memasarkan akun food blogger kepada pengguna lainnya melalui electronic word of mouth, diantaranya dengan memanfaatkan fitur pada Instagram (komentar dan direct message) dan aplikasi chat LINE dan Whatsapp. Followers melakukan E-WOM karena Instagram merupakan jejaring sosial yang menggunakan internet (cyberspace) maka dari itu pemasaran yang dilakukan bersifat elektronik.

Interaksi yang terjalin antara food blogger dan followers dapat mempererat hubungan mereka di dunia maya, maka dari itu food blogger harus senantiasa membuat interaksi dengan para followersnya. Kredibilitas food blogger dinilai dari kesesuaian dengan ulasan yang diberikan, foto yang dihasilkan, dan frekuensi mereka mengunggah konten, semakin banyak dan semakin sering akan semakin bagus, karena semakin bnyak konten yang dihasilkan maka penyebarannya akan semakin cepat.

\section{Ucapan Terima Kasih}

Dalam kesempatan ini peneliti ingin mengucapkan terimakasih kepada para narasumber (pemilik akun @makansampaikenyang: Prathama Gilang dan followersnya: Felicia Thea Djaya, Micshir Leen, Fita Franika, Maria Veronica, Martinus, Nathalya, Steffi, dan Herlina) yang telah meluangkan waktu untuk diwawancarai. Serta para dosen Fakultas Ilmu Komunikasi Universitas Tarumanagara yang telah memberikan ilmu.

\section{Daftar Pustaka}

Azeharie, Suzy. (2014). Analisis Penggunaan Twitter Sebagai Media Komunikasi Selebritis Di Jakarta. Jurnal Komunikasi. Vol 6 No. 2

<https://journal.untar.ac.id/index.php/komunikasi/article/view/35/17>

Febrina, Rachel. (2018). Pemanfaatan Media Sosial (Instagram) Oleh Fashion Blogger Dalam Menginspirasi Style Para Viewers. <http://ejournal.bsi.ac.id/ejurnal/index.php/ecodemica/article/view/1426/pdf> 
KomInfo. (2016). Mengenal Generasi Milenial. 27 Desember 2016. $<$ https://www.kominfo.go.id/content/detail/8566/mengenal-generasimillennial/0/sorotan_media> diunduh 29 November 2018

KumparanStyle. (2017). Ini Alasan Mengapa Food Blogger Jadi Profesi Yang Menggiurkan. 3 Agustus 2017.

<https://kumparan.com/@kumparanstyle/ini-alasan-mengapa-foodblogger-jadi-profesi-yang-menggiurkan> diunduh 15 Oktober 2018

Moleong, Lexy J. (2009). Metodologi Penelitian Kualitatif. Bandung: PT Remaja Rosdakarya

Ollie. (2012). Creative Blog Writing. Jakarta: Mediakita

Priansa, Donni Juni. (2017). Komunikasi Pemasaran Terpadu Pada Era Media Sosial. Jakarta: CV. Pustaka Setia

SindoNews. (2015). Food Blogger Makin Diincar. 16 Februari 2015. $<$ https://lifestyle.sindonews.com/read/964786/152/food-blogger-makindiincar-1424052558> diunduh 11 Oktober 2018

SlideShare. (2018). Digital in 2018 in Southeast Asia Part 2. 29 Januari 2018. $<$ https://www.slideshare.net/wearesocial/digital-in-2018-in-southeast-asiapart-2- southeast-86866464> diunduh 27 September 2018

Sugiyono. (2011). Metode Penelitian Pendidikan (Pendekatan Kuantitatif, Kualitatif, dan $R \& D)$. Bandung: Alfabeta

Syahbani, Fariz \& Widodo, Arry. (2017). Food Blogger Instagram: Promotion Through Social Media. Ecodemica. Vol 1 No. 1 April 2017, 48-49

Yin K. Robert, Prof. (2011). Studi Kasus; Desain dan Metode. PT. RajaGrafindo Persada. Jakarta 